\title{
What to expect in 2014
}

\section{Nature takes a look at what is in store for science in the new year.}

\section{TRANSGENIC MONKEYS}

Several research groups, including a team led by geneticist Erika Sasaki and stem-cell biologist Hideyuki Okano at Keio University in Tokyo, hope to create transgenic primates with immune-system deficiencies or brain disorders. This could raise ethical concerns, but might bring us closer to therapies that are relevant to humans (mice can be poor models for such disorders). The work will probably make use of a gene-editing method called CRISPR, which saw rapid take-up last year.

\section{SPACE PROBES}

The European Space Agency's Rosetta spacecraft could become the first mission to land a probe on a comet. If all goes well, it will land on comet ChuryumovGerasimenko in November. Mars will also be a busy place: India's orbiter mission should arrive at the planet in September, about the same time as NASA's MAVEN probe. And NASA's Curiosity rover should finally make it to its mission goal, the slopes of the 5.5-kilometrehigh Aeolis Mons, where it will look for evidence of water. Back on Earth, NASA hopes to launch an orbiter to monitor atmospheric carbon dioxide.

\section{NEURAL FEATS}

Neurobiologist Miguel Nicolelis at Duke University in Durham, North Carolina, has developed a brain-controlled exoskeleton that he expects will enable a person with a spinal-cord injury to kick the first ball at the 2014 football World Cup in Brazil. Meanwhile, attempts are being made in people with paralysis to reconnect their brains directly to paralysed areas, rather than to robotic arms or exoskeletons. In basic research, neuroscientists are excited about money from big US and European brain initiatives, such as Europe's Human Brain Project.

\section{NOVEL DRUGS}

In the pharmaceutical industry, all eyes are on trial results from two competing antibody treatments that harness patients' immune systems to fight cancer. The drugs, nivolumab and lambrolizumab, work by blocking proteins that prevent a person's $\mathrm{T}$ cells from attacking tumours. In early tests, the drugs evoked a better level of response in patients

than ipilimumab, a similar therapy that was launched in 2011 to treat advanced melanoma.

\section{RENEWABLE REVOLUTION}

Semiconductors known as perovskites convert light energy into electricity. They are cheap to build and have already shown conversion rates of more than 15\% (a leap from $4 \%$ when the feat was first reported in 2009). Expect to see still-higher efficiencies this year, perhaps

S

The Intergovernmental Panel on Climate Change will complete its fifth assessment report by November. The findings of working groups II and III will focus on the impacts of climate change, and on how societies can adapt to or mitigate those effects (working group I published its findings last year). Away from formal negotiations, United Nations secretary-general Ban Ki-moon is hoping for "bold pledges" on emissions at a summit in New York in September. In research, a large carbon capture and storage project in Canada - the Can\$1.24-billion (US\$1.17-billion) Boundary Dam coal power-plant in Saskatchewan - begins commercial operation in April.

\section{MAKING WAVES}

The European Space Agency's Planck satellite team should release data on how the polarization of photons from the Universe's

reaching $20 \%$ - the same as the lower end of existing commercial silicon-based photovoltaics. A team at the University of Oxford, UK, also hopes to make lead-free perovskites.

\section{HIV HOPE}

In 2013, two research teams showed that 'broadly neutralizing' antibodies that target an array of HIV types quickly cleared an HIVrelated virus in monkeys. The therapy will be tested in people who carry HIV, with results expected in the autumn. Meanwhile, last year's curing of a baby born with the virus might lead to wider trials of the technique used: high doses of antiretroviral drugs given at birth.

\section{MINIATURE SEQUENCER}

Technology that rapidly sequences DNA as it is fed through a ring of proteins, known as a biological nanopore, will hit the market this year after decades of development. Oxford Nanopore Technologies in Oxford, UK, aims cosmic microwave background varies across the sky. This esoteric pattern is thought to have been generated by 'inflation', the rapid expansion of the Universe after the Big Bang. If it can be detected, its details could provide evidence of relic gravitational waves, thought to have perturbed space-time in the early Universe.

\section{STEM-CELL REGENERATION}

A Japanese team will start the first clinical trials using induced pluripotent stem cells this year but don't expect results anytime soon. And biotechnology firm Advanced Cell Technology in Santa Monica, California, says that it will release data from two trials using human embryonic stem cells - the only two to gain approval from US drug regulators. These two studies involve injecting stem-cell-derived retinal cells into the eyes of around 30 people with one of two forms of non-treatable degenerative blindness.

COMPILED BY RICHARD VAN NOORDEN 